DOI 10.31558/2519-2949.2019.2.6

УДК $342.7 ; 316.4$

ORCID ID: https://orcid.org/0000-0001-6864-4425

Поліщук І. О., Національний юридичний університет імені Ярослава Мудрого

\title{
ВПЛИВ ЗМІ НА СВІДОМІСТЬ ДІТЕЙ В ОКУПОВАНИХ РАЙОНАХ ДОНЕЦЬКОЇ ТА ЛУГАНСЬКОЇ ОБЛАСТЕЙ
}

\begin{abstract}
У статті розкриваються сучасні загрози для інформаиійної безпеки дітей на окупованих територіях за умов гібридної війни в контексті перспективи їх реінтеграції у сочіально-політичне поле Украйнської держави. Інформачійна війна є важлвим складовим чинником гібридної війни, яку розгорнула Російська Федерачія протии суверенної Украӥни. Така форма боротьби є сукупністю методів та способів впливу на інформаиійну сферу: від одноразової акиії інформачійнопсихологічного та інформаційно-технічного впливу до комплексу дій, які передбачають спланований, систематичний вплив на свідомість і поведінку людей шляхом поширення упередженої, неповної чи недостовірної інформації з метою схилення їх до вчинення дій, вигідних для суб'єкта інформаиійного вплив.

Агресивна антиукраїнська пропаганда ведеться зараз на усіх телеканалах РФ і ретранслюється на окуповані украӥнські території. Відверта брехня, зневалсливе ставлення до очільників Украӥнської держави підривають їх легітимність, формують у дитячій свідомості неадекватне ставлення до дійсності, підривають начіональну ідентифікацію, формують спаплюжене ставлення до Збройних сил України як до «загарбників», а не захисників Батьківщини. Сьогодні медіа-середовище, створене на окупованих РФ українських територіях, є агресивним та негуманним.

Робиться висновок, що повернення Україною контролю над тимчасово окупованими територіями є перспективою не найближчого часу, але вже зараз украйнські можновладиі мають задумуватися над стратегією реінтеграчиї даних територій та громадян, що на них проживають. Особливо ие стосується дітей та підлітків, адже вони змушені формувати свій політичний світогляд у ворожому до Украӥни інформаційному та соціокультурному середовищі.
\end{abstract}

Ключові слова: дитина, інформачійна війна, Украӥна, Росія, громадська думка, ЗМІ.

Постановка проблеми. Вже понад 5 років на Сході України відбувається збройне протистоння між Україною та російськими найманцями, внаслідок чого окремі райони Донецької та Луганської області опнинилися під владою маріонеткових режимів Кремля - так званих «Луганської народної республіки» та «Донецької народної республіки».

Доля людей, які опинилися під владою псевдонародних республік, відтоді перестала залежати від дій українського уряду. Діти, які залишилися на окупованих Росією територіях, змушені були змиритися з вибором своїх батьків та зростають за умов не тільки збройного протистояння а й інформаційної війни. Для цих дітей на перший план висувається проблема інформаційної агресії та інформаційної безпеки.

Інформаційна війна $є$ важлвим складовим чинником гібридної війни, яку розгорнула Російська Федерація протии суверенної України. Така форма боротьби є сукупністю методів та способів впливу на інформаційну сферу: від одноразової акції інформаційно-психологічного та інформаційно-технічного впливу до комплексу дій, які передбачають спланований, систематичний вплив на свідомість i поведінку людей шляхом поширення упередженої, неповної чи недостовірної інформації з метою схилення їх до вчинення дій, вигідних для суб'єкта інформаційного впливу [1, с.20-30].

Головним об'єктом інформаційних атак є свідомість окремої людини, прихований вплив на яку здійснюється через іiі психіку та нервову систему, переважно на підсвідомому рівні «в обхід свідомого контролю, через сферу неусвідомлюваних, нечітко усвідомлюваних і несвідомих реакцій людської психіки» [2]. Вікова специфіка дитини спричиняє ту особливість, що прихований вплив на її психіку є значно більшим, ніж на дорослу людину, тому загрози для іiї інформаційної безпеки $€$ більш істотними та наочними.

Аналіз останніх досліджень. Проблему інфораційно-психологічного протистояння в сучасному соціумі вивчають у своїх працях Зубок Ю., Гончарова О., Баранов О., Брижко В., Арістова I., 
Жарков Я., Присяжнюк М., Савінова Н., Петрик В., Пилипчук В. Бєляков К., Фіоктістов А. та інші науковці. Разом з тим слід наголосити на тому, що проблема негативного впливу інформаційної війни саме на дитячу свідомість та поведінку залишається на сьогодні мало дослідженою та потребує більш ретельного вивчення.

Формулювання цілей статті. Звідси, метою даної статті є розкриття сучасних загроз для інформаційної безпеки дітей на окупованих територіях ОРДЛО за умов гібридної війни в контексті перспективи їх реінтеграції у соціально-політичне поле Української держави.

Виклад основних положень. Найбільш помітним та шкідливим проявом негативного інформаційного впливу на людину є деструктивний інформаційний вплив. Поняття «деструкція» походить від латинського destructio, що у перекладі означає «руйнація, руйнування». Сучасне трактування терміну «деструкція»- це порушення або руйнування нормальної структури чогось» $[3 ; 4$, с.255]. Звідси деструктивний інформаційний вплив на свідомість дитини - це негативний вплив, який викликає порушення цілісності особистості, руйнування ії ментальності та незворотніх порушень у іiі психіці, унеможливлює нормальнее становлення та формування особистості.

Звичайно, основним інструментом деструктивного інформаційного впливу виступає пропаганда. Сутність пропаганди полягає в маніпулюванні свідомістю, для досягнення поставленої мети їй необхідно викликати певні емоції у людей, а її основною функцією є створення вигаданої, паралельної реальності [1,c.24].

Агресивна антиукраїнська пропаганда ведеться зараз на усіх телеканалах РФ і ретранслюється на окуповані українські території. Прикладами такої пропаганди, спрямованої на дитячу аудиторію на сході країни, є мультфільм «Одного разу наше життя змінилося» на російському телеканалі «Улыбка ребенка», який буцімто створили діти-біженці з Донбасу. У цьому фейковому продукті показується, як українська армія нібито бомбардує їх рідні міста за допомогою авіації [5], новорічна дитяча казка «Спасенное Рождество», оприлюднена на офіційному каналі «ДНР» [6], ілюстрований дитячий журнал «Вежливые человечки», який розповсюджували у м.Луганську [7]. Відверта брехня, зневажливе ставлення до очільників Української держави підривають їх легітимність, формують у дитячій свідомості неадекватне ставлення до дійсності, підривають національну ідентифікацію, формують спаплюжене ставлення до Збройних сил України як до «загарбників», а не захисників Батьківщини. Перекручується сам зміст того, що відбувається на луганській та донецькій землі: російські окупанти подаються як «визволителі», а українські визволителі як «окупанти». Хоча насправді територія ОРДЛО - це українські етнічні території, де переважають представники українського народу (щоправда у меншій пропорції, ніж в інших областях України за виключенням Кримської автономії, де чисельно переважають етнічні росіяни). Звідси ніяких об'єктивних підстав для будь-якої автономії у складі України у Донбаса немає і бути не може. Уся специфіка даного регіону полягає у тому, що він через географічну близькість до РФ постійно знаходився в іноземному інформаційному полі та сформував специфічну напіврадянську самосвідомість та регіональний патріотизм, який не зовсім узгоджувався з українською ідентичністю. Але це істотне недопрацювання Української держави, яка дозволила порушити свій інформаційний суверенітет, що врешті решт призвело до порушення нашого територіального суверенітету через іноземну окупацію 3 боку Російської Федерації. У підсумку формується покоління етнічних українців на окупованих та прилеглих до них територіях, які позбавлені національної самосвідомості, не дотичні до своєї національної культури та мови та не сприймають позитивно Україну як власну Батьківщину. Це проблема, яку доведеться вирішувати не одне десятиліття.

Проблема інформаційної безпеки дітей на непідконтрольних Україні територіях ОРДЛО має загальногуманітарний та суспільно-політичний аспект.

Поняття «медіа» налаштовує нас на те, що:

- життедіяльність дітей проходить не тільки в реальному, а й уштучно створеному віртуальному, світі, у якому спілкування опосередковані електронними засобами інформації (мас-медіа);

- діти знаходяться під впливом великих обсягів фрагментованої, в основному аудіовізуальної інформації, що має превалювання афективної складової над когнітивною, а це спричиняє особливий характер засвоєння інформаційних повідомлень;

- у поле подібного, ідентичного інформаційного впливу одномоментно потрапляє велика кількість людей, адже медіа-середовище характеризується масованим впливом на великі аудиторії, які сегментуються на велику кількість адресних груп. 
Вплив інформаційного простору на дитину має іноді вирішальне значення на формування майбутньої особистості. Рівень свідомості, моральної вихованості людини визначається за їі здатністю цінувати найвищі цінності - щирість, доброту, людяність. Але які особистісні цінності переважають сьогодні і які чинники впливають на їх формування? На сьогодні одним з головних таких чинників є засоби масової інформації. Чим же сповнений інформаційний простір навколо нас?

Сьогодні сформувалися певні індикатори, які дають підстави визначати медіа-середовище, створене в ОРДЛО, як агресивне та негуманне. Це наступні характерні риси: 1) надмірний обсяг в інформаційному полі насильства, агресії, жорстокості (медіа-насильства); 2) надзвичайно висока маніпулятивна складова, яка виявляється у намаганні чинити постійний психологічний тиск на світогляд, почуття й поведінку не тільки споживачів інформаційного продукту, а й тих, хто знаходиться поруч з ними в одних соціальних мережах, контактних групах; 3) штучна нестабільність та турбулентність, які сприяють появі загального відчуття ненадійності, а отже, породжують фрустрацію, страх, невпевненість у завтрашньому дні тощо.

Для тотального впливу на масову свідомість мешканців окупованих РФ українських територій використовуються традиційні мас-медіа: телебачення, радіо, преса, книги, носії зовнішньої реклами тощо. Причому треба віддати належне росіянам, які мають високу кваліфікацію у проведенні інформаційних кампаній, операцій та взагалі у веденні інформаційної війни.

На сучасному етапі доводиться констатувати у переважної більшості дітей на окупованих територій поширення медіа-залежності, слабкий спротив насадженню низькопробної медіапродукції, аморальних цінностей, вразливість до медіа-маніпуляцій, невміння відрізнити фейкові новини від справжніх, низький рівень медіа-культури та політичної культури загалом.

Окремо слід згадати у цьому контексті вплив телебачення. Попри заборону до 22 годин, ефірний час на ТБ заповнений бойовиками зі сценами кровопролиття, бійок, насилля, улюблені кіногероями мас виступають костоломи. Жорстокість стає розхожим стереотипом нашого часу, а скромність - пороком. Цікавою розвагою, навіть дитячою, стали фільми жахів, де «героями» виступають огидні монстри. У кінопрокаті домінує нестача елементарного етикету. Глядачі сміються над грубими кінокомедіями, де треба веселитися, коли людина падає, страждає, потрапляючи у прикрі ситуації.

При цьому слід підкреслити негативний вплив телебачення та кіноманії на фізіологію дітей. Сюди відноситься: змушена нерухомість, порушення моторного розвитку, дефіцит у формуванні функцій головного мозку, порушення мовлення, порушення в адекватному сприйманні світу. До аномальних наслідків надмірного впливу ТБ на здоров'я дитини слід віднести: зупинку акомодації (рухів) очей, гіпнотичний стан сну наяву, вплив на обмін речовин, звуження поля зору до 6-7 градусів в організмі, гальмування у формуванні індивідуальної волі і самостійності, порушення у формуванні творчих, креативних здібностей.

Відбувається пригнічення природної активності дітей. Переживання за персонажів, навіть яскраві й емоційно насичені, не потребують власне ніякої дії, на відміну від реального життя, де емоція обов'язково реалізується в дії. Відірвані від дії бажання здатні підірвати майбутню мотивацію, пригнітити природну активність дитини.

Може спостерігатися відставання у розвитку мовлення. Діти пізніше починають говорити, говорять неохоче, словниковий запас бідний і примітивний. Оволодіння мовою в ранньому віці відбувається лише в живому безпосередньому спілкуванні з іншими людьми. Якщо слова не звернені до неї особисто і не вимагають відповіді, це не сприяє розвитку мовних навичок.

Вкрай негативним наслідком впливу ТБ $є$ порушення здатності до концентрації уваги. Найчастіше це проявляється, коли дитина йде до школи. Вона не може зосередитися на одній справі більше 3-5 хвилин, ій важко сидіти на уроці, потрібно рухатись. Безкінечний калейдоскоп на екрані 3 картинок, музики, обривчастих фраз. Швидкість кадрів не дає можливості усвідомити побачене. Дитині не вистачає фантазії. Дитина втрачає здатність і бажання чимось займатися. Їй нудно малювати, конструювати, вигадувати сюжети ігор. Малюк звикає до пасивного сприйняття інформації. I в житті чекає, коли хтось для нього зробить щось веселе і цікаве. Подані не з голосу близької людини (тобто без синхронізації ритмів в єдиній енергоінформаційній системі), відчужені екранні візуальні образи здатні гальмувати власні фантазії дитини, а отже, основи ії творчої активності.

Часто відбувається порушення у спілкуванні дітей з однолітками. Дітям важко вступати в ефективну комунікацію з друзями. Маленькій людині стає легше натиснути кнопку і чекати нових 
розваг, ніж налагоджувати комунікацію з іншими. У кращому випадку діти просто вовтузяться або штовхаються.

Виникає агресивність як повсякденна модель поведінки. За даними різноманітних соціологічних досліджень, $60 \%$ дітей не боїться ні власної, ні чужої смерті, вважають «розборки» звичайною нормою життя, як і бійку, виявляють епізодичні напади жорстокості. Від народження діти не володіють здатністю критично мислити, це формується тривалий період, 3 досвідом, 3 формуванням особистості. Все, що оточує сприймається як норма! Учені з’ясували, що лише $50 \%$ батьків намагаються пояснити дитині негативні сторони насилля, що демонструється на телебаченні, а 40\% не надають значення змісту програм, які дивляться їхні діти. Вплив телебачення на дітей різного віку є неоднаковим. До 2 років дітям екран взагалі не потрібен, він заважає здоровому психофізіологічному розвитку. Штучне гальмування тілесної активності дитини в ранньому віці може призвести до довготривалих негативних психологічних наслідків. Після 3 років, коли для дитини важливі однолітки як партнери для спільних ігор, відсутність контакту 3 телевізором може робити дитину дуже відмінною від загалу і погіршити їі соціалізацію.

Підлітки перевіряють свої обмеження, прагнуть ризикованої, захоплюючої поведінки. Перегляд фільмів із насильством дає їм можливість умовно задовольнити свої потреби в гострих відчуттях, пережити збудження, відчути «адреналін». На цю потребу накладається вплив груп ровесників, який теж сягає свого піку в підлітковому віці. Юнаки часто мають певне відчуття конкуренції в групі при перегляді фільмів із насильством, яке підштовхує до продовження переглядів. Проте, підлітки схильні переоцінювати себе при перевірці власних меж і часто лишаються переляканими після перегляду особливо вражаючих фільмів жахів, які важко переварити навіть дорослим. Передбачається, що старшим підліткам та дорослим, які не люблять таких фільмів, повинна бути надана можливість узяти відповідальність за рішення дивитися чи не дивитися їх. Саме для цього і використовуються відповідні позначки, які часто ігноруються власниками телемереж.

Таким чином, повернення контролю над тимчасово окупованими територіями $\epsilon$ перспективою не найближчого часу, але вже зараз українські можновладці мають задумуватися над стратегією реінтеграції даних територій та громадян, що на них проживають. Особливо це стосується дітей та підлітків, адже вони змушені формувати свій політичний світогляд у ворожому до України інформаційному та соціокультурному середовищі. Наслідки цього процесу можуть бути не прогнозованими та швидше за все негативними.

У звязку з цим, можна зробити загальні рекомендації щодо нейтралізації негативного впливу сучасних 3МІ на дитячу свідомість, які може використати будь-який вихователь та рекомендації для Української держави щодо впливу на свідомість мешканців окупованих територій 3 метою їх реінтеграції на Батьківщину.

Рекомендаиії щ⿻одо нейтралізачиї негативного впливу на дітей засобів масової інформачії

1. Необхідно розвивати медіа-освіту як надзвичайно важливий та актуальний напрям освіти. Головний напрям медіа-освіти - це інтеграція досвіду і нарощування ресурсного ставлення до медіа. До юнаків-старшокласників необхідно звертатися як до майбутніх батьків, здатних узяти на себе відповідальність не лише за своє життя, але і за нове життя.

2. Варто формувати психологічно-комфортне «виховне» середовище в сім'ї на засадах довірливої, толерантної міжособистісної взаємодії батьків й учнів. Це найвагоміша умова розвитку позитивного самопочуття дитини, набуття моральних цінностей.

3. Необхідно розвивати захоплення учнів медіа-інформацією, що задовольняє пізнавальні інтереси, здібності, моральні цінності учнів, допомагає нейтралізувати їхню увагу й надмірний потяг до сюжетів насильства на телеекрані чи в інших засобах масової комунікації.

4. Для нейтралізації негативного впливу мас-медіа на поведінку дітей, розвитку у них критичного ставлення до засобів медіа вихователям доцільно знати причини й мотиви їхнього захоплення тематикою насильства, що переважає в медіа-інформації та інших інформаційних продуктах.

5. Слід формувати у дітей імунітет до різноманітних моделей агресії, що зображуються в засобах масової інформації, нейтралізує їх негативний вплив на особистість.

6. У тому випадку, коли діти виявляють надмірну прив'язаність до фільмів, телепрограм зі сценами насильства, батькам доцільно разом з дітьми переглядати цю медіапродукцію й скеровувати їхню увагу, переживання на головні ідеї змісту, позитивні моральні вчинки, соціальні цінності, що розкриваються на екрані та поза ним. 
7. Необхідно привчати дітей до творчості, розвивати уних критичне мислення. Це спонукатиме їх обачливо, застережливо та критично дивитися на засоби масової інформації та продукти, які вони виробляють.

Для Української держави необхідно відновити вплив на свідомість мешканців окупованих територій з метою їх реінтеграції на Батьківщину та зробити наступне:

- створення спеціальних PR-програм для дітей з формування позитивного іміджу реформованої політичної системи України;

- широке впровадження з боку держави через різноманітні ЗМІ просвітницьких програм з роз'яснення виборцям їх прав, електоральних процедур, системи виборів тощо;

- створення багаторічної широкомасштабної PR-програми „Ми- українці!” з поєднанням елементів комерційної та соціальної реклами з метою формування патріотичного світогляду з залученням відомих спортивних та естрадних зірок, лідерів громадської думки;

- сприяння політичній соціалізації громадян через їх залучення до участі в політичному житті держави (членство в політичних партіях, громадсько-політичних об'єднаннях, участь у виборах, референдумах, зборах тощо);

- широке використання в політичних PR-проектах національних демократичних традицій, ідеалів та цінностей;

- реанімування вітчизняного кіновиробництва та створення циклу фільмів про історичних та сучасних героїв України.

Преспективи подальших досліджень пов'язані з розгортанням ситуації в ОРДЛО, новими ініціативами новообраного Президента України В.Зеленського та можливих змін у позиції України з приводу виконання Мінських угод, або їх перегляду.

\section{Бібліографічний список:}

1. Я Жарков, Інформаційно-психологічне протиборство (еволюція та сучасність). К.: ПАТ Віпол, 2013, 248 с.

2. Г.Грачев, Информационно-психологическая безопасность личности: состяние и возможности психологической защиты. М.: Изд-во РАГС, 1998, 125 с.

3. В.Крамаренко, Токсикологічна хімія / Фармацевтична енциклопедія [Електронний ресурс]. Режим доступу: http://pharmencyclopedia.com.ua/article/2474/desrukciya.

4. Словник української мови: у 11 т./ редкол.: І.Білодід (голова) та інші; Акад.наук Укр.РСР, Ін-т мовознавства ім.О.О.Потебні. К.: Наук. думка, 1970-1980. Т.2, 1971, 552 с.

5. Suddenly our life changed (Однажды наша жизнь изменилась) [Електронний ресурс]. Режим доступу: http://www.yuotube.com/watch? $\mathrm{v}=\mathrm{MshQF} 4 \mathrm{~g} 2 \mathrm{Lm} 4$.

6. Спасенное Рождество[Електронний ресурс]. Режим доступу: http://www.yuotube.com/watch? $=0 \mathrm{~g} 7 \mathrm{li} 4 \mathrm{C} 2 \mathrm{DVg} /$.

7. Презентация первого детского журнала ЛНР «Вежливые человечки» состоялась в Луганске ) [Електронний ресурс]. Режим доступу: http://www.yuotube.com/watch?v=MshQF4g2Lm4.

\section{References:}

1. Y. Zharkov, Information-psychological confrontation (evolution and modernity). K .: Pyotr Vital, 2013, 248 p., (in Ukrainian).

2. G.Grachev, Information and psychological security of the person: the co-operation and possibilities of psychological protection. M .: Izg. RAGS, 1998, 125 p., (in Russian).

3. V.Kramarenko, Toxicological Chemistry / Pharmaceutical Encyclopedia [Electronic resource]. Access mode: http://pharmencyclopedia.com.ua/article/2474/desrukciya. (in Ukrainian).

4. Dictionary of the Ukrainian language: 11 tons / redkol .: I. Bilyodid (head) and others; Akad.Nauk Ukr.SSR, Institute of Linguistics named after A.O.Potebni. K .: Science. thought 1970-1980. T.2, 1971, 552 p. (in Ukrainian).

5. Suddenly our life changed (Once our life has changed) [Electronic resource]. Access mode: $\mathrm{http}: / / \mathrm{www}$. yuotube.com/watch? $\mathrm{v}=\mathrm{MshQF} 4 \mathrm{~g} 2 \mathrm{Lm} 4$, (in Russian).

6. Savage Christmas [Electronic resource]. Access mode: http://www.yuotube.com/watch? $\mathrm{v}=0 \mathrm{~g} 7 \mathrm{li} 4 \mathrm{C} 2 \mathrm{DVg} /$, (in Russian).

7. Presentation of the first children's magazine LNP "Wise Men" was held in Lugansk) [Electronic resource]. Access mode: http://www.yuotube.com/watch?v=MshQF4g2Lm4, (in Russian).

\section{region}

Polishchuk I. O. The influence of media on knowledge of children in closed districts of Donetsk and Lugansk

The article reveals the current threats to the information security of children in the occupied territories in the context of the hybrid war in the context of the prospect of their reintegration into the socio-political field 
of the Ukrainian state. Information operations play a significant role in the hybrid warfare of the Russian Federation to sovereign Ukraine. Such a form of struggle is a combination of methods and methods of influencing the information sphere: from a one-time action of information-psychological and informational and technical influence to a complex of actions that involve planned, systematic influence on the consciousness and behavior of people by spreading biased, incomplete or inaccurate information for the purpose of inclining them to commit actions that are beneficial to the subject of information influence. An outright lie, a disdainful attitude towards the leaders of the Ukrainian state undermine their legitimacy, form an inadequate attitude towards reality in the child's mind, undermine national identity, and form a fierce attitude toward the Ukrainian Armed Forces as "invaders," not defenders of the Motherland. Today, the media environment created in the occupied Russian Federation in Ukrainian territories is aggressive and inhumane. It is concluded that the return of Ukraine to the temporarily occupied territories is not a short-term prospect, but now Ukrainian authorities have to think about the strategy of reintegration of these territories and citizens living there. This is especially true for children and adolescents, since they are forced to shape their political outlook in an informative and socio-cultural environment hostile to Ukraine. The conclusion is made on the necessity of creating special PR-programs for children to form a positive image of the reformed political system of Ukraine.

Key words: child, information war, Ukraine, Russia, public opinion, mass media. 